\title{
Social and economic benefits of secondary prevention of arterial hypertension
}

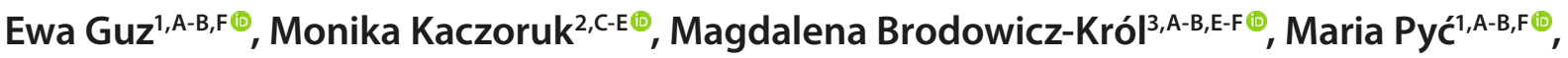 \\ Mariusz Sutryk ${ }^{1, A-B, F}{ }^{\oplus}$, Piotr Lutomski ${ }^{2, E-F} \oplus$, Piotr Choina ${ }^{2, E-F}{ }^{\oplus}$, Małgorzata Goździewska ${ }^{2, E-F}{ }^{\text {, }}$ \\ Paulina Kaczor-Szkodny ${ }^{2, C, E-F} \oplus$ \\ ${ }^{1}$ University of Economics and Innovation, Lublin, Poland \\ ${ }^{2}$ Institute of Rural Health, Lublin, Poland \\ ${ }^{3}$ Medical University, Lublin, Poland \\ A - Research concept and design, B - Collection and/or assembly of data, C - Data analysis and interpretation, \\ $D$ - Writing the article, $E$ - Critical revision of the article, $F$ - Final approval of article
}

Guz E, Kaczoruk M, Brodowicz-Król M, Pyć M, Sutryk M, Lutomski P, Choina P, Goździewska M, Kaczor-Szkodny P. Social and economic benefits of secondary prevention of arterial hypertension. Ann Agric Environ Med. 2021; 28(2): 319-325. doi: 10.26444/aaem/134221

\begin{abstract}
Introduction. Arterial blood pressure is one of the main vital signs reflecting body functions and, at the same time, the most important functional parameter of the cardiovascular system. High blood pressure is the major modifiable cardiovascular risk factor.

Objective. The aim of the study was assessment of the frequency of occurrence of cardiovascular risk factors, with particular consideration of arterial blood pressure.

Material and method. The study was conducted among 509 volunteers from Lublin in eastern Poland who participated in the prophylactic programme entitled 'White Sunday'. Standard measurements of blood pressure were performed using a TM-Z dial pressure gauge. The level of arterial blood pressure and socio-demographic parameters were analyzed.

Results. Hypertension was more frequently observed in the group of males than females. The age group especially vulnerable to abnormal blood pressure values were those aged 51-60. Isolated hypertension significantly more often occurred in the group of respondents who mentioned hypertension in an interview, compared to those who reported its absence. Among 367 persons who, in preliminary interview, did not declare hypertension, 60 cases of isolated arterial hypertension were noted (16.3\%). From among respondents who declared absence of hypertension in an interview, the largest age group diagnosed with isolated arterial hypertension were those aged 61-70 (17.9\%).

Conclusions. Arterial hypertension is a civilisation disease which may be effectively prevented, simultaneously reducing the risk of premature death due to cardiovascular events, as well as reducing social and economic costs. International health organizations recommend the implementation of social screening programmes in order to diagnose high blood pressure and the promotion of routine measurements of arterial blood pressure.
\end{abstract}

\section{Key words}

hypertension, isolated arterial hypertension, arterial hypertension, prevention, prophylaxis

\section{INTRODUCTION}

Arterial blood pressure is one of the main vital signs reflecting body functions and, at the same time, the most important functional parameter of the cardiovascular system. Blood pressure is the amount of pressure exerted by blood against the walls of blood vessels. Its level depends on the force of contraction of the ventricles, the tension of resistance vessels and blood volume [1]. Repeatable and reliable measurements of blood pressure became possible for the first time in 1896 thanks to the Italian physician Scipione Riva-Rocci, who invented a sphygmomanometric cuff for the measurement of systolic blood pressure. From 1905, due to the observations by the Russian surgeon Nikolai Korotkov, it has become possible to determine both systolic and diastolic blood pressure levels $[2,3]$. The multifactorial, complex character of arterial blood pressure was first described in 1949 by Irvine Page who proposed the Mosaic Theory of arterial hypertension. At present, the most frequently used non-

Address for correspondence: Monika Kaczoruk, Institute of Rural Health Jaczewskiego 2, 20-090 Lublin, Poland

E-mail: monika.kaczoruk@gmail.com

Received: 21.12.2020; accepted: 12.03.2021; first published: 19.03.2021 invasive methods for the measurement of the value of arterial blood pressure, which are crucial from the diagnostic and therapeutic aspects, is the use of auscultatory or oscillometric sphygmomanometers [4]. Due to 'The Framingham Heart Study', it became possible to identify standards for arterial blood pressure and the level of cholesterol as risk factors for cardiovascular diseases and atrial fibrillation, as well as the factor increasing the risk of stroke [5].

The above-mentioned studies indicated that the risk of occurrence of cardiovascular events is higher among persons diagnosed with arterial hypertension [5], the consequences of which are a major public health problem. A high level of arterial blood pressure is a basic modifiable factor of cardiovascular risk [6]. In turn, among modifiable risk factors of arterial blood pressure, apart from life style, the problem of environmental pollution is also mentioned. At the beginning of 2021, international organizations, i.e. the World Heart Federation (WHF), American College of Cardiology (ACC), American Heart Association (AHA), and the European Society of Cardiology (ESC), published a joint statement concerning the cause-effect relationship concerning the effect of environmental pollution on health. Air pollution is the key risk factor of cardiovascular diseases, and the main factor 
contributing to the global burden of disease. The statement called for structural actions in order to reduce pollutant emissions in order to limit the development of diseases, including those associated with the cardiovascular system [7]. An earlier statement by the European Society of Cardiology also indicated air pollution as one of the major modifiable risk factors for heart and vascular diseases [8].

It is estimated that in the general world population the number of persons with systolic blood pressure above normal (SBP $<140 \mathrm{~mm} \mathrm{Hg}$ or higher) has increased from 442 million in 1990 up to 874 million in 2015. Hypertension rates have increased from $17,307 / 100,000$ in 1990 up to 20,525/100,000 in 2015. The majority of deaths associated with arterial hypertension are related with cardiovascular diseases [9]. The World Health Organization (WHO) indicates that arterial hypertension causes about $12.8 \%$ of all deaths on a global scale. This means 57 million years of life lost (DALYs measure $=3.7 \%$ ) [10]. Arterial hypertension is called by the WHO 'the silent killer'. Considering its oligosymptomatic or even asymptomatic character, the majority of persons with arterial hypertension are not aware of the presence of a health problem. Therefore, it is important to carry out a prophylactic strategy on the level of the general population $[11,12]$. It is expected that a decrease in the level of arterial hypertension in the general population by only $2 \mathrm{mmHg}$ will result in the reduction of the incidence of arterial hypertension by $17 \%$, the risk of stroke by $14 \%$, and the risk of coronary disease by $6 \%[12]$.

The above-mentioned recommendation has been included in the policy called the 'Global action plan for the prevention and control of NCDs 2013-2020'. The WHO, in association with the American Centers for Disease Control and Prevention (CDC), indicated the strategic direction of actions concerning the necessity for the reduction of uncontrolled arterial hypertension by $25 \%$ by 2025 in the world population [11].

In addition, the World Health Organization has prepared effective methods for the prevention of modifiable risk factors. It indicates that due to 5 technical packages it is possible to reduce arterial hypertension. These packages include: the HEARTS project (solutions to improve hypertension control in primary health care), MPOWER (tobacco control), ACTIVE (package for increasing physical activity), SHAKE (for salt reduction), and REPLACE (to eliminate trans-fatty acids) [11].

An important element of the actions is an increase in the social awareness of arterial hypertension. Therefore, international health organizations, such as the WHO or CDC, recommend the implementation of social screening programmes, in order to diagnose high pressure in persons from the groups at high risk, and promotion of routine measurements of arterial blood pressure. Similarly, the United Nations (UN), target 3.4 of the 2030 Agenda for Sustainable Development indicates the necessity for reduction in premature mortality from non-communicable diseases, including those resulting from abnormal level of arterial blood pressure [13].

In the context of prophylactic strategy the Global Roadmaps developed by the World Heart Federation (WHF) are noteworthy for identifying the potential barriers to effective prevention, detection and treatment of cardiovascular diseases, together with evidence-based solutions enabling their practical implementation. Roadmaps have become direction indicators facilitating the realization of national prophylactic programmes to achieve the goal specified in the UN sustainable development strategy. In 2015, the roadmap was published concerning arterial hypertension, which indicated, among others, the necessity to carry out the general population strategy concerning an early detection of abnormal level of arterial blood pressure [14].

\section{OBJECTIVE}

The aim of the study was evaluation of the frequency of occurrence of risk factors for cardiovascular diseases, with particular consideration of the level of arterial blood pressure, according to international recommendations,

\section{MATERIALS AND METHOD}

The study was conducted among 509 volunteers from the city of Lublin in eastern Poland who participated in the prophylactic programme entitled 'White Sunday'. The respondents' mean age was 57.7. The majority of persons participating in the prophylactic programme were aged $61-70$ ( $\mathrm{N}=179 ; 37.1 \%)$. Seniors constituted the largest group - in 'White Sunday' in which 276 persons aged over 60 participated, i.e. $54.2 \%$ (compared to adults at productivity age: $\mathrm{N}=191,37.5 \%$ ). The study group included 367 respondents who declared in an interview that they had no arterial hypertension, while 142 persons who, in the preliminary interview, reported the presence of arterial hypertension were excluded from the study. Examinations performed within the "White Sunday' programme concerned the measurement of blood pressure, and determination of the glucose level in blood. The presented study focused on analysis of the results of arterial blood pressure. The 'White Sunday' allowed measurement outside the doctor's office, at the same time, providing a more neutral environment for a patient, which could considerably contribute to the reduction of the stressor related with a visit to a medical facility and the effect of so-called 'white coat' syndrome [15]. According to the guidelines by the Polish Society of Hypertension (PTNT), a basis for the diagnosis of arterial hypertension is a properly performed measurement with the use of an arm cuff with a certificate of accuracy [16]. The measurements were performed using a validated apparatus with a TM-Z dial gauge. The measurement was performed by the non-invasive classic auscultatory method. The PTNT guidelines also indicate the necessity for carrying out physical examinations for a more comprehensive image of cardiovascular risk, which would include risk factors of a modifiable or non-modifiable character. Therefore, in the presented study a survey method was also applied using a brief questionnaire, the results of which allowed analysis of socio-demographic variables concerning age, gender, place of residence, education level, past and/or present diseases, as well as medications taken.

The study was conducted during July-October in 2019. The results obtained were statistically analyzed using the software SPSS 24.0 with license. Differences between variables were assessed by means of non-parametric $C h i^{2}$ test for independence, and Pearson's chi-squared goodness of fit test. 


\section{RESULTS}

The respondents were qualified to categories according to socio-demographic characteristics, i.e. age, gender, education, and place of residence. The study included $65.3 \%$ of females $(\mathrm{N}=240)$ and $34.6 \%$ of males $(\mathrm{N}=127)$. Considering the fact that the prophylactic action was carried out in the city and commune of Lublin, the majority of respondents participating in the screening programme were urban inhabitants $(86.1 \%$ urban inhabitants, $13.9 \%$ rural inhabitants). Among the respondents participating in the study dominated those who had secondary school education: $49.8 \%$, followed by higher education $42.2 \%$, whereas $7.9 \%$ of respondents had primary school education.

In accordance with the applicable guidelines by the European Society of Cardiology (ESC) and the European Society of Hypertension (ESH), arterial hypertension is classified as optimal, normal, and high normal. Arterial hypertension is defined as a systolic pressure $\geq 140 \mathrm{~mm} \mathrm{Hg}$ and/or diastolic pressure DBP $\geq 90 \mathrm{~mm} \mathrm{Hg}$. Three stages of arterial hypertension are distinguished. It is also allowable to diagnose hypertensive disease when the value of blood pressure from a single measurement exceeds 180/110 $\mathrm{mm} \mathrm{Hg}$, and factors that could increase this value were excluded [17] These values are based on evidence from many randomized, controlled clinical trials which confirmed that the treatment of patients with such values of blood pressure brings about clinical benefits. The same classification refers to young and middle-aged persons, as well as older patients, whereas in children and adolescents, calculated percentiles are used [17]. Table 1 presents the frequency of occurrence of particular categories of blood pressure in the examined group (with consideration of persons with hypertension in the interview and those who declared absence of hypertension).

Table 1. Values of arterial blood pressure

\begin{tabular}{|c|c|c|c|c|c|c|}
\hline \multicolumn{7}{|c|}{ Blood pressure category } \\
\hline $\begin{array}{l}\text { Hypertension in } \\
\text { interview }\end{array}$ & 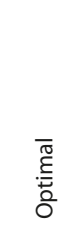 & $\begin{array}{l}\bar{\pi} \\
\stackrel{5}{0} \\
z\end{array}$ & 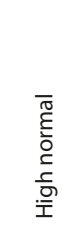 & 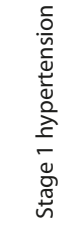 & 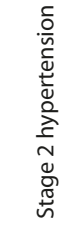 & 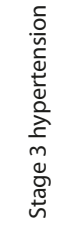 \\
\hline Absent & 74 & 101 & 63 & 93 & 30 & 6 \\
\hline$\%$ & 20.16 & 27.52 & 17.17 & 25.34 & 8.17 & 1.63 \\
\hline Present & 4 & 19 & 19 & 71 & 23 & 6 \\
\hline$\%$ & 2.82 & 13.38 & 13.38 & 50.00 & 16.20 & 4.23 \\
\hline Total & 78 & 120 & 82 & 164 & 53 & 12 \\
\hline
\end{tabular}

In the majority of respondents (47.6\%) arterial pressure was normal. In the examined group without hypertension, in an interview, $20.16 \%$ of respondents had an optimal pressure, $27.52 \%$ - normal pressure, and $17.17 \%$ - normal high pressure. In turn, in the group not qualified for the study, an optimal level of the parameter was noted in $2.82 \%$ of persons. As many as $13.38 \%$ of persons not qualified for the further stage of the study due to the presence of hypertension in an interview, had normal blood pressure values. A relatively large number of study participants had high normal blood pressure, both in the study group and the group not qualified for further stages of investigations (17.17\% and $13.38 \%$, respectively).

According to the $\mathrm{WHO}$, the majority of people with hypertension are not aware of the existing health problem, only 1 per 5 persons undertook activity in the area of prophylaxis of this health disorder [18]. Arterial hypertension is most often an asymptomatic disease, the diagnosis of which is possible due to well organized population screening. In the examined group declaring the absence of hypertension, 129 cases of hypertension were diagnosed of stage 1, 2 and 3 (25.3\%; 8.2\%, 1.6\%, respectively) (Tab. 1). Statistical analysis demonstrated that the distribution of the level of blood pressure in the group with hypertension in the interview, differed from the distribution of the level of blood pressure in the group without hypertension in the interview (Pearson's $\left.\mathrm{Chi}^{2}=58.26 ; \mathrm{p}<0.001\right)$.

In the examined group, a relationship was also confirmed between blood pressure parameters and gender (Tab. 2).

Table 2. Level of blood pressure and gender

\begin{tabular}{lccc}
\hline & \multicolumn{3}{c}{ Level of blood pressure } \\
\hline Gender & Normal & Hypertension & Total \\
\hline Female & 166 & 74 & 240 \\
\hline Male & 69.17 & 30.83 & 127 \\
\hline$\%$ & 72 & 55 & \\
\hline Total & 56.69 & 43.31 & 367 \\
\hline Pearson's Chi & 238 & 129 & $\mathrm{p}$ \\
\hline
\end{tabular}

Hypertension was more frequently observed in the group of males $(43.31 \%$ of males participating in the study who declared absence of hypertension in the interview), compared to the group of females (30.83\% of females).

Statistically significant relationships were also noted with respect to respondents' education level. Abnormal values of arterial blood pressure were more often found in persons with lower education level (Tab. 3).

Table 3. Level of blood pressure and education

\begin{tabular}{lccc}
\hline & \multicolumn{3}{c}{ Level of blood pressure } \\
\hline Education & Normal & Hypertension & Total \\
\hline Primary school & 13 & 16 & 29 \\
\hline Secondary school & 44.83 & 55.17 & \\
\hline$\%$ & 110 & 73 & 183 \\
\hline Higher & 60.11 & 39.89 & 155 \\
\hline$\%$ & 115 & 40 & 367 \\
\hline Total & 74.19 & 25.81 & $\mathrm{p}$ \\
\hline Pearson's Chi2 & 238 & 129 & 0.00163 \\
\hline
\end{tabular}

Analysis of the level of hypertension according to respondents' age also provided important data (Tab. 4).

The analyses performed demonstrated that the age group especially vulnerable to abnormal values of blood pressure 
Table 4. Level of blood pressure and age

\begin{tabular}{|c|c|c|c|}
\hline \multirow[b]{2}{*}{ Age } & \multicolumn{3}{|c|}{ Level of blood pressure } \\
\hline & Normal & Hypertension & Total \\
\hline Up to 20 years & 13 & 3 & 16 \\
\hline$\%$ & 81.25 & 18.75 & \\
\hline $21-30$ years & 15 & 7 & 22 \\
\hline$\%$ & 68.18 & 31.82 & \\
\hline $31-40$ years & 37 & 13 & 50 \\
\hline$\%$ & 74.00 & 26.00 & \\
\hline $41-50$ years & 37 & 17 & 54 \\
\hline$\%$ & 68.52 & 31.48 & \\
\hline $51-60$ years & 21 & 25 & 46 \\
\hline$\%$ & 45.65 & 54.35 & \\
\hline $61-70$ years & 78 & 39 & 117 \\
\hline$\%$ & 66.67 & 33.33 & \\
\hline 71 years and over & 37 & 25 & 62 \\
\hline$\%$ & 59.68 & 40.32 & \\
\hline Total & 238 & 129 & 367 \\
\hline \multirow{2}{*}{ Pearson's Chi ${ }^{2}$} & \multirow{2}{*}{12.48491} & df & $\mathrm{p}$ \\
\hline & & 6 & 0.052 \\
\hline
\end{tabular}

are those aged between 51-60 (Tab. 4). The occurrence of hypertension was observed in more than half of the respondents (54.4\%) in this age interval. The second age group with abnormal arterial blood pressure, according to numbers, were persons aged 71 and over. Statistical analysis indicted the presence of a relationship between age and the level of blood pressure $\left(\mathrm{Chi}^{2}\right.$ Pearson=11.8; $\left.\mathrm{p}<0.03\right)$. It should also be indicated that in the case of the remaining age groups, the occurrence of arterial hypertension is not a rare phenomenon, despite low numbers of respondents at younger age; in each group a minimum of one-fourth of cases of hypertension were noted.

Considering the fact that the prophylactic action was carried out in the city of Lublin and the Lublin commune, urban inhabitants constituted a large percentage of the screening participants, compared to the number of persons living in the rural areas who participated in the study ( $86.1 \%$ vs $13.9 \%)$. Therefore, the performance of an analysis considering the respondents' place of residence was not advisable due to the risk of incorrect inference.

Isolated arterial hypertension is also important in the interpretation of arterial blood pressure. Isolated hypertension means repeated elevated values of systolic blood pressure (SBP) in combination with normal diastolic blood pressure (DBP) [19]. At present, isolated systolic or systolic-diastolic hypertension is considered as the main sub-type of arterial hypertension in young adults, in whom it has been considered as a 'deceptive status', resulting from the enhancement of the 'normal' central blood pressure, where the pressure waves transit through peripheral vessels [20].

Isolated hypertension was significantly more often observed in the group of respondents who declared hypertension in the interview $(45.07 \%$ of persons who mentioned hypertension in the interview), compared to those who reported the absence of hypertension (16.35\% of respondents in this group). However, it should be emphasized that from among 367 persons who declared absence of arterial hypertension in the preliminary interview, 60 cases of isolated arterial hypertension were noted (16.3\%). The largest age group among respondents who declared absence of hypertension in the interview, in whom isolated hypertension was diagnosed, were those aged $61-70(17.9 \%)$. While analyzing the situation in individual age groups, it was observed that in the age group 51-60 it was the lowest, although there was a still high percentage of persons without isolated arterial hypertension (76.1\%) (Tab. 5).

Table 5. Isolated hypertension according to age.

\begin{tabular}{|c|c|c|c|}
\hline & \multicolumn{3}{|c|}{ Isolated hypertension } \\
\hline Age & NOT isolated & Isolated & Total \\
\hline $1+2)$ up to 20 years & 15 & 1 & 16 \\
\hline$\%$ & 93.75 & 6.25 & \\
\hline 3) $21-30$ years & 18 & 4 & 22 \\
\hline$\%$ & 81.82 & 18.18 & \\
\hline 4) $31-40$ years & 46 & 4 & 50 \\
\hline$\%$ & 92.00 & 8.00 & \\
\hline 5) 41-50 years & 48 & 6 & 54 \\
\hline$\%$ & 88.89 & 11.11 & \\
\hline 6) 51-60 years & 35 & 11 & 46 \\
\hline$\%$ & 76.09 & 23.91 & \\
\hline 7) 61-70 years & 96 & 21 & 117 \\
\hline$\%$ & 82.05 & 17.95 & \\
\hline 8+9) 71 and over & 49 & 13 & 62 \\
\hline$\%$ & 79.03 & 20.97 & \\
\hline Total & 307 & 60 & 367 \\
\hline \multirow{2}{*}{ Pearson's Chi ${ }^{2}$} & \multirow{2}{*}{7.989552} & df & $\mathrm{p}$ \\
\hline & & 6 & 0.23888 \\
\hline
\end{tabular}

Table 6. Isolated hypertension according to gender

\begin{tabular}{lccc}
\hline & \multicolumn{3}{c}{ Isolated hypertension } \\
\hline Gender & NOT isolated & Isolated & Total \\
\hline Females & 209 & 31 & 240 \\
\hline Males & 87.08 & 12.92 & \\
\hline$\%$ & 98 & 29 & 127 \\
\hline Total & 77.17 & 22.83 & 367 \\
\hline Pearson's Chi & 307 & 60 & $\mathrm{p}$ \\
\hline
\end{tabular}

Analyses showed that this type of hypertension also depended on respondents' age. Isolated hypertension was more often observed in males (22.83\%) than females (12.92\%). (Tab. 6).

Statistical analysis did not show any significant differences between education level and place of residence, and the occurrence of isolated systolic arterial hypertension (Tab. 7). 
Table 7. Isolated hypertension according to education and place of residence

\begin{tabular}{|c|c|c|c|}
\hline \multirow{2}{*}{ Education } & \multicolumn{3}{|c|}{ Isolated hypertension } \\
\hline & NOT isolated & Isolated & Total \\
\hline Primary school & 23 & 6 & 29 \\
\hline$\%$ & 79.31 & 20.69 & \\
\hline Secondary school & 149 & 34 & 183 \\
\hline$\%$ & 81.42 & 18.58 & \\
\hline higher & 135 & 20 & 155 \\
\hline$\%$ & 87.10 & 12.90 & \\
\hline Total & 307 & 60 & 367 \\
\hline \multirow[t]{2}{*}{ Pearson's Chi ${ }^{2}$} & \multirow{2}{*}{2.410802} & df & $\mathrm{p}$ \\
\hline & & 2 & 0.29958 \\
\hline Place of residence & NOT isolated & Isolated & Total \\
\hline Urban area & 266 & 50 & 316 \\
\hline$\%$ & 84.18 & 15.82 & 100.00 \\
\hline Rural area & 41 & 10 & 51 \\
\hline$\%$ & 80.39 & 19.61 & 100.00 \\
\hline Total & 307 & 60 & 367 \\
\hline \multirow{2}{*}{$\begin{array}{l}\text { Chi }^{2} \text { with Yates' } \\
\text { Correction }\end{array}$} & \multirow{2}{*}{0.2248833} & df & $\mathrm{p}$ \\
\hline & & 1 & 0.63535 \\
\hline
\end{tabular}

\section{DISCUSSION}

Arterial hypertension is a civilisation disease which may be effectively prevented and, at the same time, reduces the risk of premature death due to cardiovascular events, as well as the social and economic costs incurred [21]. Excessively high blood pressure is directly related with the occurrence of cardiovascular diseases, such as myocardial infarction, cerebral stroke, heart failure, or peripheral artery disease [22]. An abnormal value of arterial blood pressure may also constitute a direct cause of death. In 2009, the WHO indicated that arterial hypertension was a direct cause of $13 \%$ of deaths worldwide [23]. Chronic non-communicable diseases, to which belongs arterial hypertension, are responsible for 90\% of deaths in the European Union (EU), and generate considerable costs for the health care system and the whole of society. According to the Organization for Economic Co-operation and Development (OECD), every year in the EU approximately 550,000 people at productivity age die prematurely due to non-communicable chronic diseases. In accordance with the data by the Directorate General Health and Consumers, the above-mentioned health disorders represent a loss of value for the EU economy of approx. 115 billion EUR, i.e. $0.8 \%$ of the GDP annually [24,25]. These diseases are the main cause of mortality, and simultaneously, the majority of health care costs. Additional losses concern the economic sector, resulting in a decrease in productivity. It has been estimated that economic growth decreases by $0.5 \%$ per each $10 \%$ of an increase in mortality due to noncommunicable chronic diseases [26]. In the document 'Business As Usual Scenario', prepared by the World Economic Forum and Harvard School of Public Health, it was indicated that in the years 2011-2025 economic losses will exceed 7 billion, which is approximately $4 \%$ of annual production in $2010[26,27]$. It is an important fact that among the noncommunicable chronic diseases there are those in which it is possible to avoid hospitalization due to effective prophylaxis. From among more than 30 diseases in the case of which it would be possible to reduce hospitalization due to actions on the level of primary healthy car, 5 diseases are distinguished as especially important in European countries: diabetes, arterial hypertension, heart failure, chronic obstructive pulmonary disease (COPD), and asthma [24]. Total costs of treatment of non-communicable chronic diseases in Poland constitute $4.3 \%$ of the GDP (indirect costs are $3.8 \%$ of GDP) [28]. Polish analyses performed by the National Health Fund indicate that in 2018 the total cost of provision of services for adults due to arterial hypertension (health services with the main diagnosis of arterial hypertension) was 258.3 million PLN. Thus, the reduction in arterial hypertension is of great importance from both the health and economic aspects.

The effectiveness of screening increases with respect to the health problems which frequently occur in a given population and for which there is an effective treatment. Therefore, an important action is pursuing stage 1 and stage 2 prophylactic actions, which allow an increase in social awareness, as well as an early detection of a health disorder which is arterial hypertension. According to guidelines by the Polish Forum for Prevention of Cardiovascular Diseases, measurement of arterial blood pressure are an effective method in stage 2 prophylaxis. Measurement should be carried out in persons without the diagnosis of arterial hypertension, starting from the age of 3 , at least once a year. In addition, in adults with blood pressure 120-139/80-89 mm Hg, this measurement should be performed more often [29].

Data by the WHO demonstrate that many people are unaware of the existing health problem which is hypertension, and almost $30 \%$ of the adult Polish population ill with arterial hypertension are not aware of this fact [30]. Author's own research showed that among persons who, in preliminary interview, declared absence of the symptoms of the disease, 129 cases of hypertension at stages 1,2 and 3 were diagnosed. This was confirmed in a study by Jarząbek et al. which demonstrated that a considerable percentage of respondents had never measured their blood pressure, and only $1 / 4$ of them could present the actual value of arterial blood pressure [31].

Awareness of the presence of risk factors of noncommunicable chronic diseases, including arterial hypertension in the Polish population, remains extremely varied and depends, among other things, on the respondents' place of residence, gender, education level, and age $[32,33]$. In the NATPOL II study, $65.5 \%$ of persons declared that they knew their blood pressure. However, in the NATPOL PLUS study, the researchers observed a decrease in the level of knowledge concerning own arterial blood pressure. This phenomenon is especially clearly observed in small towns and rural areas, where few inhabitants posses their own preion, nearly a half of persons who smoked cigarettes were unaware of the fact that they suffered from hypertension. Among non-smokers, this percentage was 35\% [36].

The presented study confirmed the above-mentioned analyses. Moreover, many prospective studies also demonstrated that total mortality and mortality due to coronary disease was higher among persons with a lower socioeconomic status, defined as low education level, low income, low occupational status, or living in poor neighbourhoods (relative risk - 1.3-2.0) [37]. Similar conclusions were drawn in the presented study and indicated that abnormal values of arterial hypertension were significantly more frequently 
diagnosed among males than females. Hypertension more often occurred in the group of males who, in the preliminary interview, declared the absence of hypertension. In the WOBASZ study, the frequency of occurrence of hypertension in males was higher than among females (42 vs. 33\%) [38]. Differences in the prevalence of hypertension according to gender changed with age. In the NATPOL PLUS study, in Poland, among persons aged between 18-39, hypertension was diagnosed in $7 \%$ of the study participants, significantly more often among males than females (11 vs. $3 \% ; p<0.05$ ). In the age group $40-59$, hypertension was diagnosed in $34 \%$ of the examined persons (34\% of females and $34 \%$ of males), whereas in the group aged over 59 , hypertension was occurred in $57 \%$ of respondents, slightly more frequently in females (60 vs. $54 \%$, statistically insignificant) [38].

A study by E. Tomiak et al. demonstrated that the implementation of prophylactic interventions based on the practice of a general physician occurred to be the most effective method for controlling epidemics of cardiovascular diseases. A larger number of prophylactic consultations resulted in a significant decrease in the mean systolic and diastolic blood pressure, and total cardiovascular risk calculated using the SCORE charts [39]. A systematic review prepared by the USPSTF concerning the determination of advantages and disadvantages resulting from intervention in the form of behavioural therapy in order to improve diet and physical activity in adults and cardiovascular risk factorsm demonstrated that these interventions result in the reduction of the incidence of cardiovascular events, decrease in blood pressure and high-density lipoproteins [40]. Interventions within the prophylaxis of the above-mentioned disease entities should focus primarily on education and the presence of the essential risk factors [41, 42].

Own studies confirmed that the largest group willing to participate in the prophylactic action were persons aged over 60 . Efforts should be made so that a larger number of persons from younger age groups participated in prophylactic examinations, because the process of development of atherosclerotic changes may begin during the period of adolescence. Recommendations by scientific societies also include the implementation of actions within the scope of early detection of cardiovascular diseases and performance of basic diagnostic tests, i.e. lipogram, measurement of body weight, BMI and the measurement of glycaemia $[43,44]$.

Programmes of primary and secondary prevention of complications of arterial hypertension should be based on early detection and control of modifiable risk factors, due to the consequent health effects, high risk of death, and costs associated with further treatment. Therefore, an effective prevention of arterial hypertension should start with the youngest age groups [45].

\section{CONCLUSIONS}

Reduction of arterial hypertension is very important, both from health and economic aspects. It is important to carry out actions within stage 1 and stage 2 prophylaxis, which enables an increase in social awareness, as well as an early detection of the health disorder which is arterial hypertension. Own study showed that among 367 persons who declared the absence of the symptoms of the disease in preliminary interview, 129 cases of hypertension were diagnosed of stages 1,2 , and 3
(25.3\%; 8.2\%, $1.6 \%$, respectively). Abnormal values of arterial blood pressure were significantly more often diagnosed in males than females. Hypertension more frequently occurred in the group of males who declared the absence of hypertension in the preliminary interview. The study demonstrated that the largest group willing to participate in the prophylactic action were persons aged over 60 . Efforts should be made in order that a larger number of persons from the younger age groups participate in prophylactic examinations to reduce damage to health and the economy.

\section{REFERENCES}

1. Konturek S. Fizjologia człowieka. Układ krążenia. Kraków: Wydawnictwo Uniwersytetu Jagiellońskiego; 2016. 2.

2. Nicolas Postel-Vinay A. Century of Arterial Hypertension 1896-1996. Chichester: Wiley; 1996.

3. Januszewicz W, Dworzański W, Prejbisz A, Januszewicz A. Nadciśnienie tętnicze wtórne - co nowego? Choroby Serca i Naczyń. 2015; 12(1): 15-18.

4. Szymański FM. Standardowe i uzupełniające metody pomiaru wartości ciśnienia tętniczeg - o czym należy pamiętać? Choroby Serca i Naczyń 2013; 10(5): 243-249.

5. Mahmood SS, Levy D, Vasan RS, Wang TJ. The Framingham Heart Study and the epidemiology of cardiovascular disease: a historical perspective. Lancet. 2014; 383(9921): 999-1008. https://doi.org/10.1016/ s0140-6736(13)61752-3

6. Stanaway JD, Afshin A, Gakidou E, Lim SS, Abate D, Abate KH, et al. Global, regional, and national comparative risk assessment of 84 behavioural, environmental and occupational, and metabolic risks or clusters of risks, 1990-2017: a systematic analysis for the Global Burden of Disease Study 2017. Lancet. 2018; 392: 1923-94. https://doi. org/10.1016/s0140-6736(18)32225-6

7. Brauer M, Casadei B, Harrington RA, Kovacs R, Sliwa K. Expert Group the WAP. Taking a Stand Against Air Pollution - The Impact on Cardiovascular Disease: A Joint Opinion from the World Heart Federation, American College of Cardiology, American Heart Association, and the European Society of Cardiology. Global Heart. 2021; 16(1): 8. http://doi.org/10.5334/gh.948

8. Newby DE, Mannucci PM, Tell GS, et al. Expert position paper on air pollution and cardiovascular disease. Eur Heart J. 2015; 36(2): 83-93. https://doi.org/10.1093/eurheartj/ehu458

9. Zhou B, Bentham J, Di Cesare M, Bixby H, Danaei G, et al. Worldwide trends in blood pressure from 1975 to 2015: a pooled analysis of 1479 population-based measurement studies with 19.1 million participants. Lancet. 2017; 389: 37-55. https://doi.org/10.1016/s0140-6736(16)31919-5

10. World Health Organization. World health statistics 2020: monitoring health for the SDGs, sustainable development goals. World Health Organization. https://apps.who.int/iris/handle/10665/332070 License: CC BY-NC-SA 3.0 IGO. (access: 2020.10.09).

11. World Health Organization. Global action plan for the prevention and control of NCDs 2013-2020. Resolution WHA66.10. https://www.who. int/publications/i/item/9789241506236 (access: 2020.10.09).

12. Carey RM, Muntner P, Bosworth HB, Whelton PK. Prevention and Control of Hypertension: JACC Health Promotion Series. J Am Coll Cardiol. 2018; 72(11): 1278-1293.

13. ONZ. Rezolucja Zgromadzenia Ogólnego A/RES/70/1: Agenda na Rzecz Zrównoważonego Rozwoju 2030. A/RES/70/1.

14. Adler AJ, Prabhakaran D, Bovet P, Kazi DS, Mancia G, et al. Reducing Cardiovascular Mortality Through Prevention and Management of Raised Blood Pressure A World Heart Federation Roadmap. Global Heart. 2015; 10(2): 111-122.

15. Pioli MR, Ritter AM, de Faria AP, Modolo R. White coat syndrome and its variations: differences and clinical impact. Integr Blood Press Control. 2018; 11: 73-79. https://dx.doi.org/10.2147\%2FIBPC.S152761

16. Polish Society of Hypertension. Principles of management of arterial hypertension - 2019. Guidelines by the Polish Society of Hypertension. Arterial Hypertension in Practice. 2019; 5(1): 1-86.

17. Whelton PK, Carey RM. The 2017 clinical practice guideline for high blood pressure. JAMA. 2017; 318(21): 2073-2074. https://doi. org/10.1001/jama.2017.18209

18. World Health Organization. Global NCD target: reduce high blood pressure. WHO. 2016. https://www.who.int/publications/i/item/globalncd-target-reduce-high-blood-pressure (access: 2020.10.09). 
19. Koracevic G. Unsolved Problem: (Isolated) Systolic Hypertension with Diastolic Blood Pressure below the Safety Margin. Med Princ Pract. 2020; 29: 301-309. doi: 10.1159/000508462

20. Kim S, Lee J, Kim W, Kim YH, et al. Central hemodynamic characteristics of young adults with isolated systolic hypertension: an ambulatory blood pressure monitoring-based study of real-world clinical patients. Hypertens Res. 2019; 43: 197-206 (2020). https://doi. org/10.1038/s41440-019-0352-1

21. Jan S, Laba TL, Essue BM, Gheorghe A, Muhunthan J, et al. Action to address the household economic burden of non-communicable diseases. Lancet. 2018; 391(10134): 2047-2058. https://doi.org/10.1016/ s0140-6736(18)30323-4

22. Choromańska A, Szumiał Sz, Czerw A. Indirect costs of arterial hypertension and its complications. J Edu Health Sport. 2019; 9(5): 265-279. http://dx.doi.org/10.5281/zenodo.3070251

23. World Health Organization. Global health risks: Mortality and burden of disease attributable to selected major risks. Geneva, Switzerland: 2009.

24. OECD/EU. Health at a Glance: Europe 2018: State of Health in the EU Cycle, OECD Publishing, Paris,2018. https://doi.org/10.1787/health_ glance_eur-2018-en (access: 2020.10.09).

25. Eurostat. Member States spent over $€ 1000$ billion on health, 2017. https://ec.europa.eu/eurostat/web/products-eurostat-news/-/DDN20170825-1 (access: 2020.10.09)

26. World Health Organization. Noncommunicable diseases: what ministries of education need to know. Geneva: World Health Organization for the UN Interagency Task Force on NCDs; 2016. https:// apps.who.int/iris/bitstream/handle/10665/250231/WHO-NMH-NMA16.93-eng.pdf?sequence $=1$ (access: 2020.10.09).

27. Bloom DE, Cafiero ET, Jané-Llopis E, et al. The Global Economic Burden of Noncommunicable Diseases. Geneva: World Economic Forum; 2011.

28. Leśniowsa J. Obciążenie systemu ochrony zdrowia i gospodarki kosztami generowanymi przez przewlekłe choroby niezakaźne. Kolegium Zarządzania i Finansów. 2018; 167: 79-93.

29. Cybulska B, Szostak WB, Filipiak KJ, et al. Polish Forum for Prevention Guidelines on Dyslipidaemia. Kardiol Pol. 2017; 75(2): 187-190. doi: 10.5603/KP.2017.0031

30. Suligowska K, Gajewska M, StokwiszewskiJ, et al. Niedostateczna wiedza Polaków na temat kryteriów nadciśnienia tętniczego i jego powikłań - wyniki badania NATPOL 2011. Nadciśnienie Tętnicze. 2014; 18(1): 9-18.

31. Jarząbek K, Kozłowska A, NiedzielaJ, et al. Knowledge of risk factors for coronary artery disease in the population of Lublin and Swietokrzyskie voivodeships in Poland. Folia Cardiolog. 2015; 10(1): 9-16.

32. Piwońska A, Piotrowski W, Piwoński J, et al. Cardiovascular health knowledge of the Polish population. Comparison of two national multi-centre health surveys: WOBASZ and WOBASZ II. Kardiol Pol.
2017; 75(7): 711-719. doi: 10.5603/KP.a2017.0070, indexed in Pubmed: 28394004 .

33. Nowicki G, Ślusarska B, Brzezicka A. Analiza stanu wiedzy o czynnikach ryzyka chorób układu sercowo-naczyniowego wśród osób pracujących. Nursing Topics. 2009; 17(4): 321-327.

34. Zdrojewski T, Wyrzykowski B, Szczęch R, et al. Steering Committees of the Programmes NATPOL PLUS; SMS: the Polish 400 Cities Project. Epidemiology and prevention of arterial hypertension in Poland. Blood Press Suppl. 2005; 2: 10-16.

35. Zdrojewski T, Rutkowski M, Bandosz P, et al. Prevalence and control of cardiovascular risk factors in Poland. Assumptions and objectives of the NATPOL 2011 Survey. Kardiol Pol. 2013; 71: 381-392.

36. Balwicki Ł, Zdrojewski T, Bandosz P, et al. Świadomość nadciśnienia tętniczego a palenie papierosów wśród dorosłych Polaków. Arterial Hypertens. 2010; 14(3): 196-200.

37. Perk J, De Backer G, Gohlke H, et al. Europejskie wytyczne dotyczące zapobiegania chorobom serca i naczyń w praktyce klinicznej na rok 2012. Kardiol Pol. 2012; 70: 1-99.

38. Zdrojewski T. Częstość występowania i świadomość nadciśnienia tętniczego w Polsce i na świecie. Post Nauk Med. 2011; 4: 4-10.

39. Tomiak E, Chlabicz S, Mizgała E, et al. Prevention of cardiovascular disease in a rural general practice. Ann Agric Environ Med. 2016; 23(4): 553-558. doi: 10.5604/12321966.1226845

40. United States Preventive Services Task Force. Risk Assessment for Cardiovascular Disease With Nontraditional Risk Factors US Preventive Services Task Force Recommendation Statement. JAMA. 2018; 320: 272-280.

41. Arent-Piotrowska K. Hipercholesterolemia - zmora dzisiejszych czasów. Co zrobić, by zapobiec jej konsekwencjom w świetle aktualnych zaleceń kardiologicznych. Probl Hig Epidemiol. 2018, 99(2): 108-113.

42. Arnett DK, Blumenthal RS, Albert MA, et al. 2019 ACC/AHA Guideline on the Primary Prevention of Cardiovascular Disease. A Report of the American College of Cardiology/American Heart Association: Task Force on Clinical Practice Guidelines. J Am Coll Cardiol. 2019; 74: 1376-1414.

43. National Institute for Health and Care Excellence. Familial hypercholesterolaemia: identification and management. https://www.nice. org.uk/guidance/cg71 (access: 2021.02.26).

44. Whelton P, Carey R, Wilbert S, et al. Guideline for Prevention, Detection, Evaluation, and Management of High Blood Pressure in Adults. J Am Coll Cardiol. 2017; 71: 127-248.

45. Krzywińska-Wiewiorowska M, Stawińska-Witoszyńska B, Krzyżaniak A, et al. Environmental variation in the prevalence of hypertension in children and adolescents - is blood pressure higher in children and adolescents living in rural areas? Ann Agric Environ Med. 2017; 24(1): 129-133. doi: 10.5604/12321966.1230678 